\title{
Article
}

\section{The Bacterial Amyloids Phenol Soluble Modulins from Staphylococcus aureus Catalyze Alpha-Synuclein Aggregation}

\author{
Caroline Haikal $^{1}$ (D), Lei Ortigosa-Pascual ${ }^{2}$, Zahra Najarzadeh ${ }^{3}$, Katja Bernfur ${ }^{2}$, Alexander Svanbergsson ${ }^{1}$ (D), \\ Daniel E. Otzen ${ }^{3}\left(\mathbb{D}\right.$, Sara Linse ${ }^{2}$ and Jia-Yi Li ${ }^{1,4} * * \mathbb{D}$
}

1 Neural Plasticity and Repair Unit, Wallenberg Neuroscience Center, Department of Experimental Medical Science, Lund University, 22184 Lund, Sweden; caroline.haikal@med.lu.se (C.H.); alexander.svanbergsson@med.lu.se (A.S.)

2 Department of Biochemistry and Structural Biology, Lund University, 22100 Lund, Sweden; lei.ortigosa@biochemistry.lu.se (L.O.-P.); katja.bernfur@biochemistry.lu.se (K.B.); sara.linse@biochemistry.lu.se (S.L.)

3 Interdisciplinary Nanoscience Centre (iNANO), Aarhus University, Gustav Wieds Vej 14, 8000 Aarhus C, Denmark; Zahra_najarzadeh@yahoo.com (Z.N.); dao@inano.au.dk (D.E.O.)

4 Health Sciences Institute, China Medical University, Shenyang 110112, China

* Correspondence: jia-yi.li@med.lu.se or lijiayi@cmu.edu.cn

check for updates

Citation: Haikal, C.; Ortigosa-Pascual, L.; Najarzadeh, Z.; Bernfur, K.; Svanbergsson, A.; Otzen, D.E.; Linse, S.; Li, J.-Y. The Bacterial Amyloids Phenol Soluble Modulins from Staphylococcus aureus Catalyze Alpha-Synuclein Aggregation. Int. J. Mol. Sci. 2021, 22, 11594. https:// doi.org/10.3390/ijms222111594

Academic Editor: Dong-Gyu Jo

Received: 20 September 2021

Accepted: 25 October 2021

Published: 27 October 2021

Publisher's Note: MDPI stays neutral with regard to jurisdictional claims in published maps and institutional affiliations.

Copyright: (c) 2021 by the authors. Licensee MDPI, Basel, Switzerland. This article is an open access article distributed under the terms and conditions of the Creative Commons Attribution (CC BY) license (https:/ / creativecommons.org/licenses/by/ $4.0 /)$.

\begin{abstract}
Aggregated $\alpha$-synuclein ( $\alpha$-syn) is the main constituent of Lewy bodies, which are a pathological hallmark of Parkinson's disease (PD). Environmental factors are thought to be potential triggers capable of initiating the aggregation of the otherwise monomeric $\alpha$-syn. Braak's seminal work redirected attention to the intestine and recent reports of dysbiosis have highlighted the potential causative role of the microbiome in the initiation of pathology of PD. Staphylococcus aureus is a bacterium carried by $30-70 \%$ of the general population. It has been shown to produce functional amyloids, called phenol soluble modulins (PSM $\alpha$ s). Here, we studied the kinetics of $\alpha$-syn aggregation under quiescent conditions in the presence or absence of four different PSM $\alpha$ peptides and observed a remarkable shortening of the lag phase in their presence. Whereas pure $\alpha$-syn monomer did not aggregate up to $450 \mathrm{~h}$ after initiation of the experiment in neither neutral nor mildly acidic buffer, the addition of different PSM $\alpha$ peptides resulted in an almost immediate increase in the Thioflavin $\mathrm{T}$ (ThT) fluorescence. Despite similar peptide sequences, the different PSM $\alpha$ peptides displayed distinct effects on the kinetics of $\alpha$-syn aggregation. Kinetic analyses of the data suggest that all four peptides catalyze $\alpha$-syn aggregation through heterogeneous primary nucleation. The immunogold electron microscopic analyses showed that the aggregates were fibrillar and composed of $\alpha$-syn. In addition of the co-aggregated materials to a cell model expressing the A53T $\alpha$-syn variant fused to GFP was found to catalyze $\alpha$-syn aggregation and phosphorylation in the cells. Our results provide evidence of a potential trigger of synucleinopathies and could have implications for the prevention of the diseases.
\end{abstract}

Keywords: alpha-synuclein; bacterial amyloids; aggregation; protein folding; Parkinson's disease

\section{Introduction}

Aggregated alpha-synuclein ( $\alpha$-syn) is a pathological hallmark of Parkinson's disease (PD), multiple system atrophy and Lewy body dementia. The majority of synucleinopathies are of idiopathic nature and the environment is thought to play a causative role. In Braak's landmark studies, $\alpha$-syn inclusions were identified in the dorsal motor nucleus of the vagus at very early stages of PD. It was hypothesized that PD pathology could be initiated peripherally, either in the gastrointestinal or the olfactory system, where it would spread to the brain $[1,2]$. Several studies in rodents have shown that $\alpha$-syn can propagate from the intestinal lumen, wall or enteric neurons to the brain [3-6]. Other studies have shown propagation of preformed $\alpha$-syn fibrils from the olfactory bulb to the amygdala and 
entorhinal cortex [7-9]. For a deeper understanding of PD and other synucleinopathies, it is of interest to examine peripheral factors, which could trigger the aggregation of the otherwise soluble $\alpha$-syn.

Both the olfactory cavities and the gastrointestinal tract harbor large numbers of microorganisms that are known to prime and modulate the immune system as well as directly modulate $\alpha$-syn aggregation. Both LPS and bacterial chaperones have been shown to affect the kinetics of aggregation and toxicity of $\alpha$-syn [10-12]. Cross-seeding of $\alpha$-syn has previously been demonstrated not only with human amyloid proteins (tau [13] and A $\beta 42$ [14]) but also with amyloid proteins of bacterial origin (Curli from E. coli) [11,15]. Several bacteria and fungi produce amyloids, which often help in the maintenance of a biofilm and adherence [16]. One such bacterium is the gram-positive Staphylococcus aureus.

S. aureus is the bacterium responsible for the majority of skin and soft-tissue infections [17] as well as a common skin, nose and even GI commensal [18-21]. S. aureus produces amyloid proteins called phenol soluble modulins (PSMs), which participate in biofilm formation. The $\alpha$ type of the PSMs comprise four different hydrophobic 20-25 amino-acid long peptides, often formylated at the $\mathrm{N}$-terminal. The $\mathrm{pH}$ modulation of their aggregation mechanisms was recently reported (41) with PSM $\alpha 1$ found to aggregate through a mechanism dominated by secondary nucleation at neutral $\mathrm{pH}$. Other factors also modulate PSM fibrillation, such as the sulfated polysaccharide heparin [22]. The production of PSM $\alpha$ peptides by $S$. aureus is stringently regulated and is associated with virulence. PSM $\alpha$ peptides are secreted by $S$. aureus at high concentrations, with high nanomolar concentrations acting as chemoattractants for neutrophils and micromolar concentrations causing cytolysis $[23,24]$. Their expression has been shown to be upregulated upon S. aureus phagocytosis by neutrophils promoting phagosome lysis and bacterial escape $[25,26]$. PSM $\alpha$ peptides can rapidly induce neutrophil extracellular trap (NET) formation [24]. Interestingly, NETs have been shown to co-localize with amyloids in human tissues [27].

$\operatorname{PSM} \alpha$ peptides produced by $S$. aureus have been shown to directly activate sensory neurons of the skin and increase firing in cultured dorsal root ganglia (DRG) neurons by disrupting membranes and forming pores, allowing cation influx and depolarization [28,29]. In contrast, they have been shown to inhibit the firing of sensory neurons in the enteric nervous system leading to modulation of the secretion and motility of the intestine [30]. Nociceptive hypersensitivity and GI disturbances have been described both in PD patients and PD rodent models. Skin biopsies have revealed small fiber neuropathies or mixed fiber polyneuropathy in PD patients [31] and Braak has described $\alpha$-syn deposits in neurons of the lamina I of the spinal cord, which directly project to the thalamus from peripheral nociceptive neurons [32]. Lewy body pathology has also been described in the enteric nervous system (ENS) [33] and neurons of the DRG [34]. PSM $\alpha$ peptides could as such interact with $\alpha$-syn in peripheral sensory neurons.

In the present study, we hypothesized that these PSM $\alpha$ peptides could modulate $\alpha$-syn aggregation. We monitored the aggregation kinetics of $\alpha$-syn in vitro upon the addition of different PSM $\alpha$ s at a range of concentrations. The PSM $\alpha$ s induced rapid aggregation of monomeric $\alpha$-syn into fibrils, which could induce seeding and phosphorylation in human embryonic kidney (HEK) cells expressing the A53T variant of $\alpha$-syn fused to green fluorescent protein (GFP).

\section{Results}

\subsection{Phenol Soluble Modulins Catalyze $\alpha$-Syn Aggregation}

We investigated whether the PSM $\alpha$ s could induce $\alpha$-syn aggregation at physiologically relevant concentrations, i.e., in the $1-100 \mu \mathrm{M}$ range. To study the effects on the kinetics under conditions where secondary nucleation strongly dominates over primary nucleation ( $\mathrm{pH} 5.5$ and low ionic strength), or conditions where secondary nucleation is less dominant ( $\mathrm{pH} 7.5$ and moderate ionic strength), the experiments were repeated in two different buffers. The PSM $\alpha$ peptides may interact with $\alpha$-syn in the cytoplasm of sensory neurons or in the extracellular space, which further motivates the inclusion of the neutral $\mathrm{pH}$ condition. 
We first monitored the aggregation kinetics of $25 \mu \mathrm{M} \alpha$-syn under quiescent conditions in the presence or absence of different PSM $\alpha$ peptides in $10 \mathrm{mM}$ Tris, $50 \mathrm{mM} \mathrm{NaCl}$, $\mathrm{pH}$ 7.6. The addition of each of the four PSM $\alpha$ peptides induced a rapid increase in ThT fluorescence, which was not observed for $\alpha$-syn incubated on its own or with DMSO at the same concentrations as used with the peptides (Figures 1 and S1). All four PSM $\alpha$ peptides significantly shortened the lag phase for $\alpha$-syn aggregation to less than $20 \mathrm{~h}$, except at the lowest concentrations of PSM $\alpha 2$ and PSM $\alpha 3$. The ThT curves plateaued before $100 \mathrm{~h}$, except in the presence of the highest concentrations of PSM $\alpha 1$ and PSM $\alpha 4$ (Figures 1 and S1). The concentration dependence was monotonic for PSM $\alpha 2$ and PSM $\alpha 3$, with the strongest catalytic effect at the highest peptide concentration tested $(78 \mu \mathrm{M})$, and biphasic for PSM $\alpha 1$ and PSM $\alpha 4$ with the strongest catalytic effect observed at 3-9 $\mu \mathrm{M}$. The results indicate that PSM $\alpha$ peptides potently catalyze $\alpha$-syn aggregation in buffers mimicking physiological conditions, rapidly increasing the ThT fluorescence intensity even at low peptide concentrations. The concentration-dependence variance between the similarly sized and charged peptides suggests that this catalysis is sequence-specific.

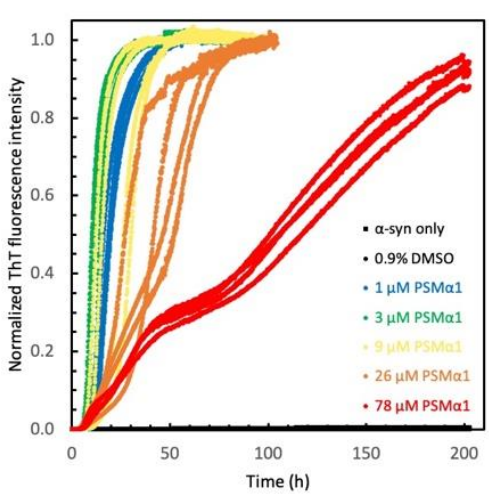

(A)

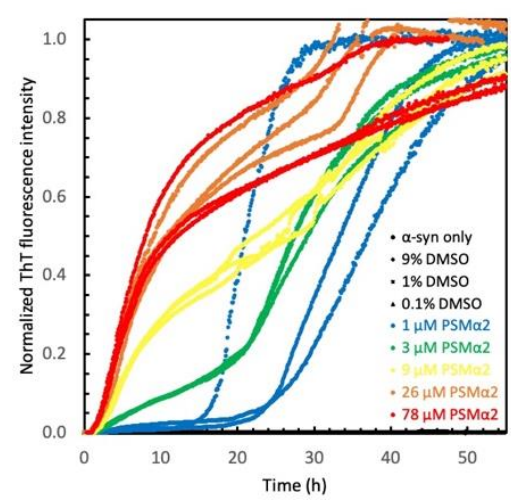

(B)

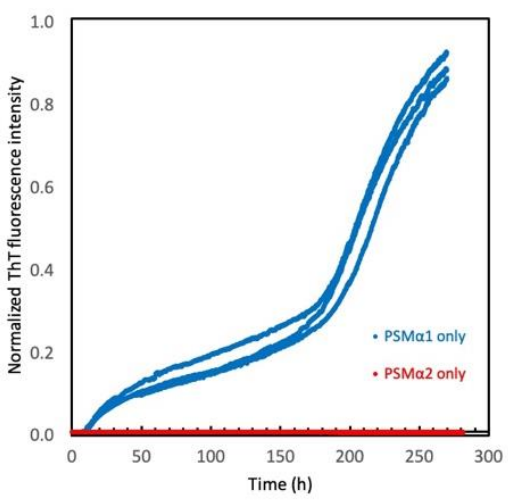

(C)

Figure 1. Aggregation of $\alpha$-syn in the presence of PSM $\alpha$ peptides. (A,B) Normalized ThT fluorescence intensity as a function of time for $25 \mu \mathrm{M} \alpha$-syn in the presence of varying PSM $\alpha 1$ (A) or PSM $\alpha 2$ (B) concentrations as provided in the respective panel. (C) Control experiments with only $78 \mu \mathrm{M}$ PSM $\alpha 1$ (blue) or $78 \mu \mathrm{M}$ PSM $\alpha 2$ (red). All experiments started from monomers and were performed in $10 \mathrm{mM}$ Tris, $50 \mathrm{mM} \mathrm{NaCl}, \mathrm{pH} 7.6$ at $37^{\circ} \mathrm{C}$ under quiescent conditions.

In mildly acidic buffer, 10 mM MES, pH 5.5 with no additional salt, all four PSM $\alpha$ peptides significantly shortened the lag phase for $\alpha$-syn aggregation to less than $20 \mathrm{~h}$, and the ThT curves plateaued before $100 \mathrm{~h}$ even at low $\mu \mathrm{M}$ PSM $\alpha$ concentrations (Figure S2). At the examined concentrations, the overall aggregation was slower at $\mathrm{pH} 7.5$ compared to 5.5 .

To verify the catalytic effect of the peptides on $\alpha$-syn aggregation, additional experiments were performed at higher $\alpha$-syn monomer concentrations, at higher $\mathrm{pH}(7.4)$ and higher salt concentration $(150 \mathrm{mM})$ in the presence of polystyrene surfaces, known to catalyze primary nucleation of $\alpha$-syn. The PSM $\alpha$ peptides were again shown to accelerate the increase in ThT fluorescence (Figure S3).

\subsection{PSM $\alpha$ Modulation of $\alpha$-Syn Aggregation Is DMSO Independent}

As the PSM $\alpha$ peptides were dissolved in DMSO, the samples with the peptide also contained DMSO, the concentration of which increased with the peptide concentration. As the PSM $\alpha-\alpha$-syn aggregated samples would later be added to cells, the lower concentrations of the peptides were not supplemented with additional DMSO. However, in one control experiment, we supplemented the different PSM $\alpha 2$ peptide dilutions with DMSO to correspond to the highest DMSO concentration $(8.9 \% v / v$, equal to $1.25 \mathrm{M})$ used in the previous experiments. The effects of the PSM $\alpha 2$ concentrations with additional DMSO on 
$\alpha$-syn were similarly examined. The kinetic curves obtained with this PSM $\alpha 2$ dilutions series show similar trends as the PSM $\alpha 2$ dilutions without supplemented DMSO (varying DMSO concentrations) (Figure S4).

To ensure that the effects on $\alpha$-syn aggregation observed were due to the peptides, and not to DMSO or impurities, one aliquot of PSM $\alpha 2$ was purified with size exclusion chromatography before the kinetics experiments. Different fractions of the central peak were added to freshly purified $\alpha$-syn monomer in $10 \mathrm{mM}$ Tris, $50 \mathrm{mM} \mathrm{NaCl}, \mathrm{pH} 7.6$ and compared to PSM $\alpha 2$ dissolved in DMSO. The results indicate similar effects of the purified $\mathrm{PSM} \alpha 2$ fractions (without any DMSO) compared to the original DMSO-dissolved peptide (Figure S5).

\subsection{PSM $\alpha$ Peptides Modulate $\alpha$-Syn Aggregation Differently}

Next, we wanted to elucidate the mechanisms underlying the PSM $\alpha$-catalyzed $\alpha$-syn aggregation. As a first step, we examined the effects of the different PSM $\alpha$ concentrations on the rate of $\alpha$-syn aggregation. The time at which ThT intensity reached half the intensity of the plateau was calculated for each concentration of the four different PSM $\alpha$ peptides and plotted against the concentration of the peptides (Figure S6). At pH 7.6, the double logarithmic plots of PSM $\alpha 1$ and PSM $\alpha 4$ indicate an optimal catalytic concentration, above and below which the lag phase is prolonged. In contrast, PSM $\alpha 2$ and PSM $\alpha 3$ exhibit linear curves, or curves that flatten out, with negative slopes, indicating a reduction of half-times as a function of concentration. This is interesting as PSM $\alpha 1$ and PSM $\alpha 4$ have previously been described to form typical fibrillar amyloid structures when aggregated on their own, as opposed to PSM $\alpha 2$ and PSM $\alpha 3$, which form $\alpha$-helix-rich fibrillar aggregates [35,36]. Indeed, in our hands, PSM $\alpha 1$ and PSM $\alpha 4$ regularly showed increases in ThT fluorescence, whereas PSM $\alpha 2$ and PSM $\alpha 3$ did not (Figure 1 and Figure S1). As such, at higher peptide concentrations, the aggregation of PSM $\alpha 1$ and PSM $\alpha 4$ could potentially occur in parallel with $\alpha$-syn aggregation. A retardation of $\alpha$-syn aggregation can also be seen upon the addition of very high concentrations of lipid vesicles [37]. This is thought to be due to the adsorption of $\alpha$-syn monomer to the membrane, effectively lowering the free monomeric $\alpha$-syn concentration. Thus, the reduced catalytic effect of $\alpha$-syn aggregation at high concentration of PSM $\alpha 1$ or PSM $\alpha 4$, but not PSM $\alpha 2$ or PSM $\alpha 3$, could indicate different affinities for $\alpha$-syn to each of the PSM $\alpha$ peptides.

\subsection{Composition of Aggregated Species}

When the interactions between $\alpha$-syn and the different PSM $\alpha$ peptides were probed by peptide arrays, $\alpha$-syn did not show any signal above cutoff for the arrays with PSM $\alpha 1$ or PSM $\alpha 4$ peptides. However, $\alpha$-syn exhibited a strong signal, indicative of high affinity binding to the PSM $\alpha 2$ sequences IIAGIIKFIK, GIIKFIKGLI, and the PSM $\alpha 3$ sequence FVAKLFKFFK (Figure S7).

Mass spectrometry was used to gain insight into whether the PSM $\alpha$ peptides formed low molecular weight heteromolecular aggregates with $\alpha$-syn. Different PSM $\alpha$ - $\alpha$-syn samples after reaching the plateau phase in the aggregation process were separated by SDS PAGE and the $<10,37$, and $120 \mathrm{kDa}$ bands were excised, subjected to in-gel digestion and analyzed with mass spectrometry. PSM $\alpha$ sequences were detected only in the lowest Mw bands $(<10 \mathrm{kDa})$. All other bands showed the presence of $\alpha$-syn but not PSM $\alpha$ (Figure S8). We thus hypothesize that the PSM $\alpha$ s induce $\alpha$-syn aggregation by transient interactions but do not become incorporated in co-aggregates.

\subsection{PSM $\alpha$ Peptides Induce $\alpha$-Syn Aggregation by Heterogeneous Primary Nucleation}

Although the data for PSM $\alpha$-induced $\alpha$-syn aggregation displaying significant deviation between repeats, models of increasing complexity were used to find out how many microscopic steps are needed to capture the observed behavior. For simplicity, these analyses ignored the biphasic curves observed at high concentration of some of the PSM $\alpha$ s. Clearly, the simplest model of primary nucleation and elongation predicts more shallow 
curves than those observed (Figures 2 and S9). The very steep transition following a relatively flat lag phase requires a model that incorporates a secondary step, i.e., a step involving $\alpha$-syn fibrils. A model of primary nucleation, elongation and secondary nucleation can reproduce most of the data in terms of curve shape and concentration dependence using a globally fitted value of the combined rate constant for secondary pathway $\left(\mathrm{k}_{+} \mathrm{k}_{2}\right)$, while the combined rate constant for primary pathway $\left(k_{+} k_{n}\right)$ was allowed to take different values at the different PSM $\alpha$ concentrations (Figure S8). The catalysis observed in the presence of PSM $\alpha$ peptides can thus be explained by the peptides inducing $\alpha$-syn aggregation through heterogeneous primary nucleation, whereas the secondary nucleation step is intrinsic to $\alpha$-syn.

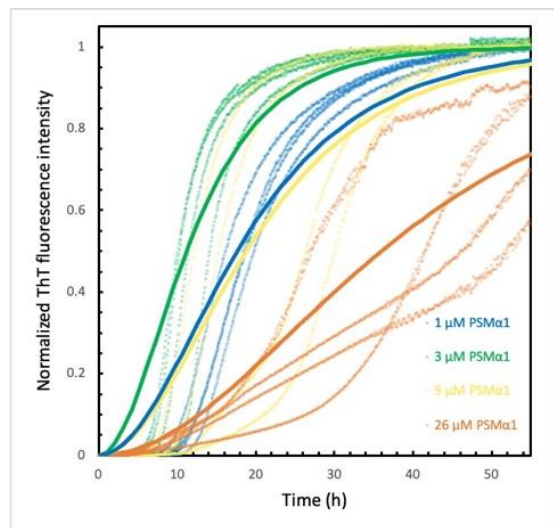

(A)

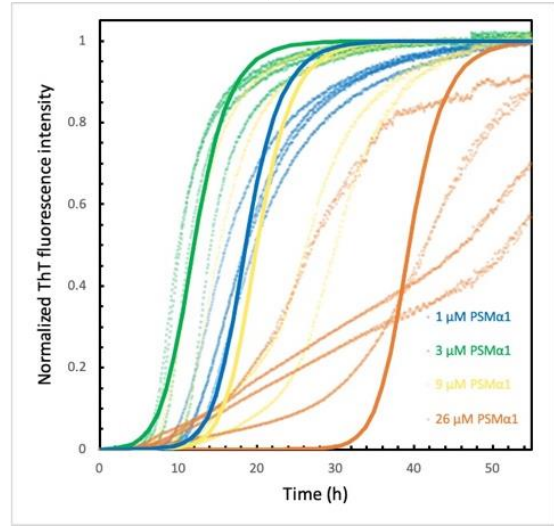

(C)

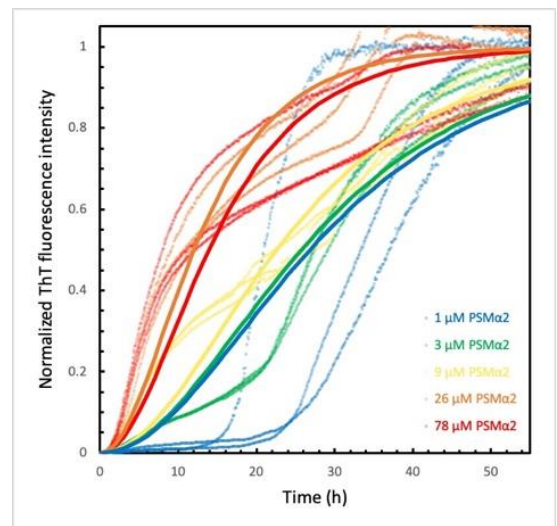

(B)

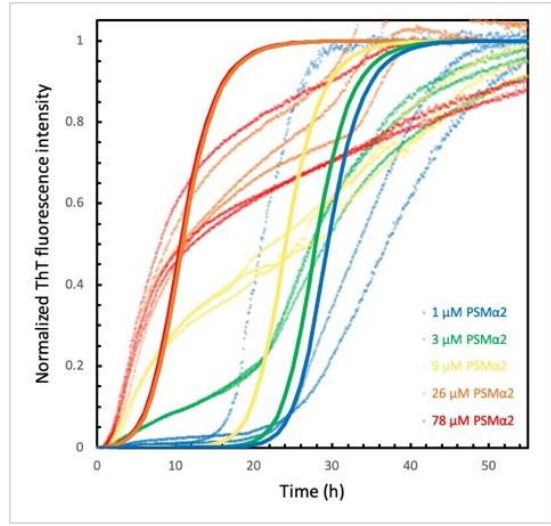

(D)

Figure 2. Fitting of models of nucleation and elongation to aggregation kinetics of $\alpha$-syn in the presence of PSM $\alpha$ peptides. The ThT fluorescence intensities as a function of time of $25 \mu \mathrm{M} \alpha$-syn aggregation induced by varying PSM $\alpha 1(\mathbf{A}, \mathbf{C})$ and PSM $\alpha 2(\mathbf{B}, \mathbf{D})$ concentrations $(\mu \mathrm{M})$ were fitted to models of primary nucleation and elongation $(\mathbf{A}, \mathbf{B})$ or to models of primary nucleation, elongation and secondary nucleation (C,D). The dotted lines are the normalized ThT fluorescence intensities and the solid lines are the fits as calculated by Amylofit. All experiments started from monomers and were performed in $10 \mathrm{mM}$ Tris, $50 \mathrm{mM} \mathrm{NaCl}$, pH 7.6 at $37^{\circ} \mathrm{C}$ under quiescent conditions.

\section{6. $\alpha$-Syn Concentration Dependence Varies for Different PSM $\alpha$ Peptides}

To examine the $\alpha$-syn-monomer-concentration-dependence of the observed catalysis, the PSM $\alpha$ peptide concentration was kept constant and $\alpha$-syn monomer concentration varied. For all peptides examined, a significant acceleration of aggregation of $\alpha$-syn can again be observed (Figure 2 and S10) compared to $\alpha$-syn without the peptide, which did not show an increase of ThT signal. For the pure peptides at $9 \mu \mathrm{M}$ total concentration, ThT is only seen to emit a signal in the presence of PSM $\alpha 1$. Interestingly, PSM $\alpha 1$ on its own, reaches the plateau faster than any of the PSM $\alpha 1-\alpha$-syn co-incubated samples. 
(Figure S10A). The aggregation curve of PSM $\alpha 1$ at $9 \mu \mathrm{M}$ follows a typical sigmoidal curve, whereas at $78 \mu \mathrm{M}$ a biphasic aggregation curve is observed (Figures S10A and $1 \mathrm{C}$ ).

For $\alpha$-syn aggregation induced by PSM $\alpha 1$, a weak monomer-concentration dependency was observed. This may imply that the number of catalytic sites for heterogenic primary nucleation are limiting, or that product release is the rate-limiting step [38].

For PSM $\alpha 2$, a biphasic aggregation curve was observed for all concentrations of $\alpha$ syn, especially obvious at 9 and $26 \mu \mathrm{M}$. A stepwise macroscopic curve may result if two different species form separate aggregates [39], if the process becomes physically restricted, e.g., due to restricted diffusion from gel formation or accumulation of intermediates at interfaces (Figure S10B) [40]. At high $\alpha$-syn monomer concentrations, the aggregation is less catalyzed than at lower $\alpha$-syn monomer concentrations. Indeed, from the previous experiment, it can also be observed that PSM $\alpha 2$-induced catalysis of $\alpha$-syn aggregation is less effective when the monomer to peptide concentration exceeds a ratio of 1:1.

Even though PSM $\alpha 3$ did not induce aggregation of $\alpha$-syn at monomer concentrations below $26 \mu \mathrm{M}$ (Figure S10C), the aggregation shows a tendency to slower aggregation at higher monomer concentration. $\alpha$-syn aggregated in the presence of PSM $\alpha 4$ (Figure S10D), on the other hand, exhibited the fastest aggregation at the highest and lowest monomer concentration, compared to the mid-range concentrations.

The peptides are all potent inducers of $\alpha$-syn aggregation, likely by heterogenous primary nucleation.

\subsection{PSM $\alpha$ Peptides Induce $\alpha$-Syn Fibril Formation}

To examine the composition of the formed aggregates, the PSM $\alpha$ peptides and $\alpha$-syn incubated together or separately were immunogold-labelled using an anti- $\alpha$-syn antibody and imaged by TEM. PSM $\alpha$-induced $\alpha$-syn aggregates were found to be fibrillar and of approximately 10-20 nm in diameter (Figures 3 and S11). $\alpha$-syn incubated on its own occasionally showed individual fibrils despite the lack of increase in ThT signal in the kinetics experiments, in agreement with the formation of significant amounts of fibrils during the lag phase, although their concentrations need to reach about $1 \%$ of the final value to be detected by ThT bulk assay [41,42]. $\alpha$-syn incubated on its own did, however, show higher background immunogold labeling, indicating high monomeric $\alpha$-syn content. All the PSM $\alpha$ peptides appeared as amorphous aggregates.

\subsection{PSM $\alpha$-Peptide-Induced- $\alpha$-Syn Aggregates Seed $\alpha$-Syn in Cells}

To investigate whether the formed $\alpha$-syn aggregates could act as seeds in cells, the aggregates formed in $\alpha$-syn-PSM $\alpha$ mixtures were added to HEK 293T cells expressing the A53T mutant form of $\alpha$-syn fused to GFP. The A53T mutant form was used as it results in a robust aggregation model [43]. After $48 \mathrm{~h}$, the cells were fixed and stained for phosphorylated $\alpha$-syn. All imaged wells showed some signal indicating aggregate formation in the cells. The quantification of the GFP aggregates is less accurate than the quantification of the phosphorylated aggregates owing to the lower signal-to-noise ratio. The aggregates formed in different PSM $\alpha$ - $\alpha$-syn mixtures showed differences in their ability to induce phosphorylation of aggregates in cells (Figures 3 and S12). $\alpha$-syn aggregated in the presence of PSM $\alpha 1$ and PSM $\alpha 4$ showed the highest phosphorylation induction at a 3:1 protein to peptide concentration ratio, whereas for PSM $\alpha 2$ and PSM $\alpha 3$, the highest phosphorylation induction was observed for protein aggregated at a 1:1 peptide concentration ratio. This is in agreement with the kinetic data, where PSM $\alpha 1$ and PSM $\alpha 4$ induce rapid $\alpha$-syn aggregation at lower concentrations than PSM $\alpha 2$ and PSM $\alpha 3$. This indicates that the concentration of PSM $\alpha$ affects the seeding potential of the formed aggregates. When cells were treated with $\alpha$-syn incubated in the absence of $\operatorname{PSM} \alpha$, no phosphorylated aggregates could be seen. 


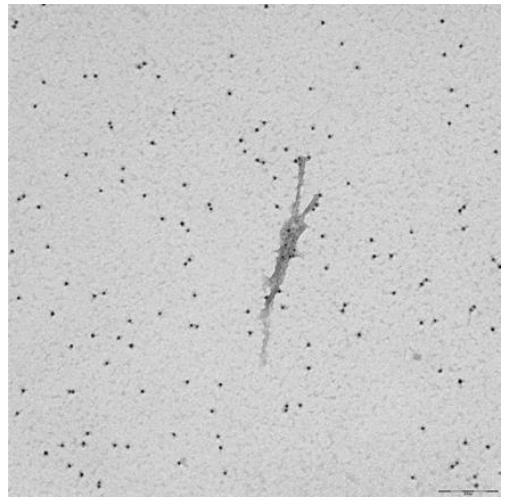

(A)

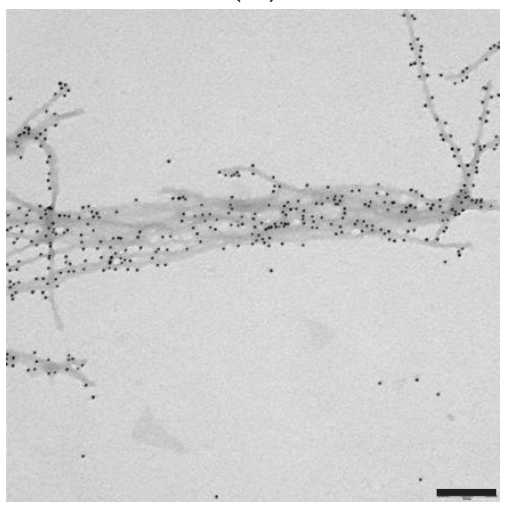

(D)

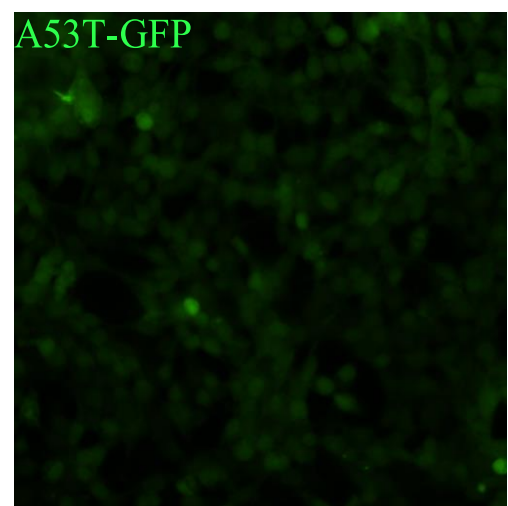

(B)

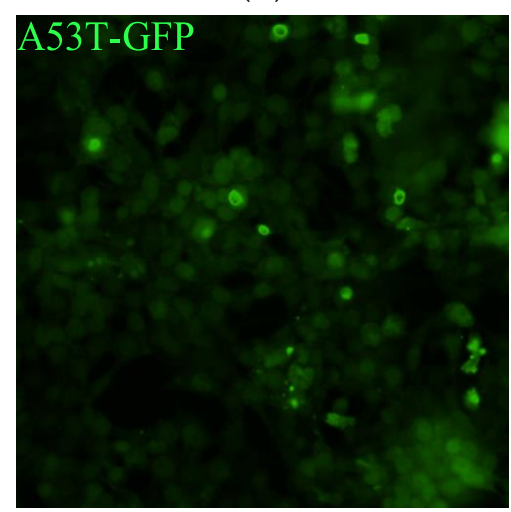

(E)

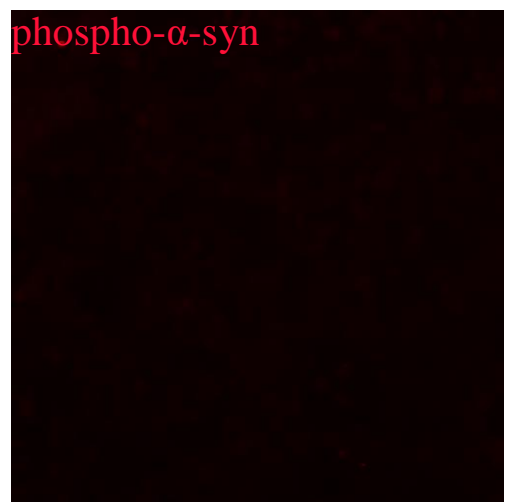

(C)

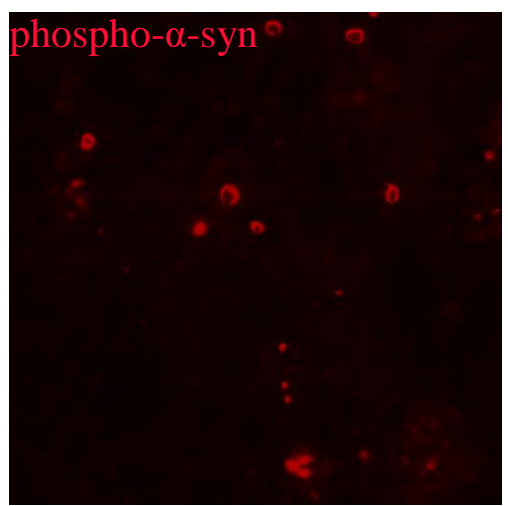

(F)

Figure 3. Microscopic images. (A,B) TEM micrographs at 60,000 times magnification of samples taken at the plateau of aggregation reactions with $25 \mu \mathrm{M} \alpha$-syn (A) in the absence or (B) presence of $9 \mu \mathrm{M}$ PSM $\alpha 1$ peptide. All experiments started from monomers and were performed in $10 \mathrm{mM}$ Tris, $50 \mathrm{mM} \mathrm{NaCl}, 1.1 \% \mathrm{DMSO}, \mathrm{pH} 7.6$ at $37^{\circ} \mathrm{C}$ under quiescent conditions. After deposition on the grids, the samples were labelled by an anti- $\alpha$-syn primary antibody (syn211) and a secondary antibody linked to $10 \mathrm{~nm}$ gold nano-particles. Scale bar $=200 \mathrm{~nm}$. (C-F). GFP and Cy-3 fluorescence microscopic images at 20 times magnification of HEK cells expressing A53T $\alpha$-syn fused to GFP. The same samples as imaged by TEM were sonicated and added at a 1:10 ratio to the cells for $48 \mathrm{~h}$ before the cells were fixed and incubated with an antibody against phosphorylated $\alpha$-syn followed by a Cy3-conjugated secondary antibody.

\section{Discussion}

$\alpha$-syn exists as an intrinsically disordered monomer in vitro, and forms aggregates in vivo under disease conditions as well as in buffer systems in vitro. After the formation of the initial aggregates, rapid amplification of the aggregate mass can occur by autocatalytic secondary nucleation or by monomer addition to existing aggregates in an elongation process [44]. However, formation of the initial seeds (de novo seed formation) in bulk solution is slow and surface catalysis seems critical. The energy barrier for homogenous primary nucleation, i.e., from monomer species in solution, is high and primary nucleation is undetectable for $\alpha$-syn at neutral $\mathrm{pH}$, at least over a typical experimental time-frame of a few weeks [45]. Heterogenous primary nucleation, on the other hand, occurs on the surface of other substances, such as polystyrene plates or nanoparticles [46] or lipid vesicles [37], or at the air-liquid interface [47]. In vivo, primary nucleation is thought to be mainly heterogenous [44]. Extrinsic inducers of aggregation would explain the role of the environment in idiopathic PD. In our current work, we identified the bacterial amyloids, formylated PSM $\alpha$ peptides produced by $S$. aureus, as potent catalyzers of $\alpha$-syn aggregation.

The $\alpha$-syn aggregation mechanism is highly dependent on solution conditions such as $\mathrm{pH}$ and ionic strength, owing to the heterogenous charge distribution of the protein [45]. At a mildly acidic $\mathrm{pH}$, the overall net negative charge of $\alpha$-syn is reduced in contrast to a neutral $\mathrm{pH}$, leading to a decrease in electrostatic repulsion between $\alpha$-syn monomers, 
and between monomers and fibrils, and an increase in aggregation propensity. High salt concentrations, on the other hand, have been shown to screen electrostatic attractions between the oppositely charged termini within or between monomers in solution and on surfaces, resulting in a retardation of aggregation [48]. In this study we show that the $\mathrm{PSM} \alpha$ peptides rapidly induce $\alpha$-syn aggregation even at neutral $\mathrm{pH}$ and moderate ionic strength. All the examined PSM $\alpha$ peptides accelerate $\alpha$-syn aggregation, although the concentration-dependence of these effects seems to differ. It is possible to explain most of the observed data, ignoring the biphasic curves observed in some concentration regimes, through the catalysis of $\alpha$-syn aggregation by primary heterogeneous nucleation with the rate of nucleation being dependent on the ratio of PSM $\alpha$ peptide to $\alpha$-syn. As illustrated in Figure 4, cross-catalysis and heterogeneous primary nucleation could, for example, occur through the formation of joint oligomers or on the surface of fibrillar forms of the peptides. The PSM $\alpha$ peptides themselves have been shown to have different $\mathrm{pH}$ and concentration dependent aggregation kinetics [49]; their different effects on $\alpha$-syn have been shown in this study. Further work may elucidate the molecular origin of the cross-catalytic effects and how it varies among the PSM $\alpha$ peptides.

Peripheral $\alpha$-syn expression is well documented and several studies have shown $\alpha$-syn propagation and seeding from the periphery to the CNS [3-6]. Thus, we studied whether the PSM $\alpha$-induced $\alpha$-syn aggregates could induce seeding in cells from a cell-line. Indeed, upon direct addition to cells, the aggregates formed in $\alpha$-syn-PSM $\alpha$ mixtures catalyzed $\alpha$-syn aggregation in the cells and increased phosphorylation of the aggregates. Again, we could see differences in this catalytic effect, depending on which PSM $\alpha$ was present and its concentration. Likewise, in the aggregation kinetics, we have seen a clear dependence of the aggregation rate on the ratio of peptide to $\alpha$-syn. This implies that the aggregates formed in $\alpha$-syn-PSM $\alpha$ mixtures are potent inducers of $\alpha$-syn aggregation and phosphorylation in cells.

Our current work identifies PSM $\alpha$ peptides as potent extrinsic inducers of $\alpha$-syn aggregation and potential triggers of $\alpha$-syn pathology. Our current work also highlights the concentration-dependent interactions of the PSM $\alpha$ peptides and $\alpha$-syn monomer on the aggregation kinetics and the triggering of aggregation in cells. This supports that underly genetic predispositions and bacterial load could affect the pathological outcome. Previous studies have shown propagation of aggregated $\alpha$-syn from peripheral tissues to the CNS. Our work identifies a mechanism by which the original seeds of $\alpha$-syn could arise in the periphery. Figure 4C illustrates a potential mechanism whereby an S. aureus infection could trigger a cascade of NETosis and increased PSM $\alpha$ production catalyzing $\alpha$-syn aggregation in peripheral tissues. S. aureus is also a commensal bacterium, colonizing an estimated $30 \%$ of the population. Although the PSM $\alpha$ peptides contribute to biofilm formation, it is still debated whether S. aureus biofilm formation is present in non-infection scenarios [50]; to our knowledge, no study has yet examined the expression of these peptides in commensal situations. With S. aureus infections continuing to rise globally, with the elderly population especially affected, host-pathogen interactions will gain further interest from the research and medical fields. The current results have significant implications for the understanding of $S$. aureus in initiation of $\alpha$-syn pathology in different synucleinopathies, such as PD. 


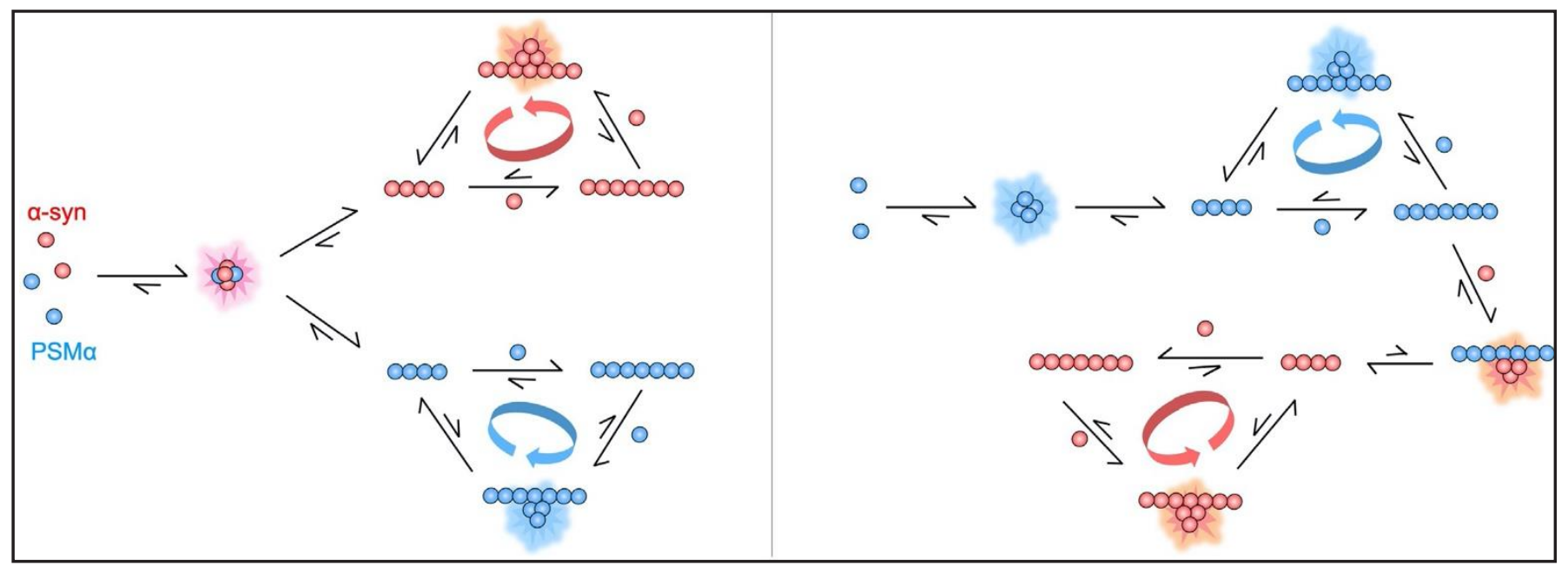

(A)

(B)

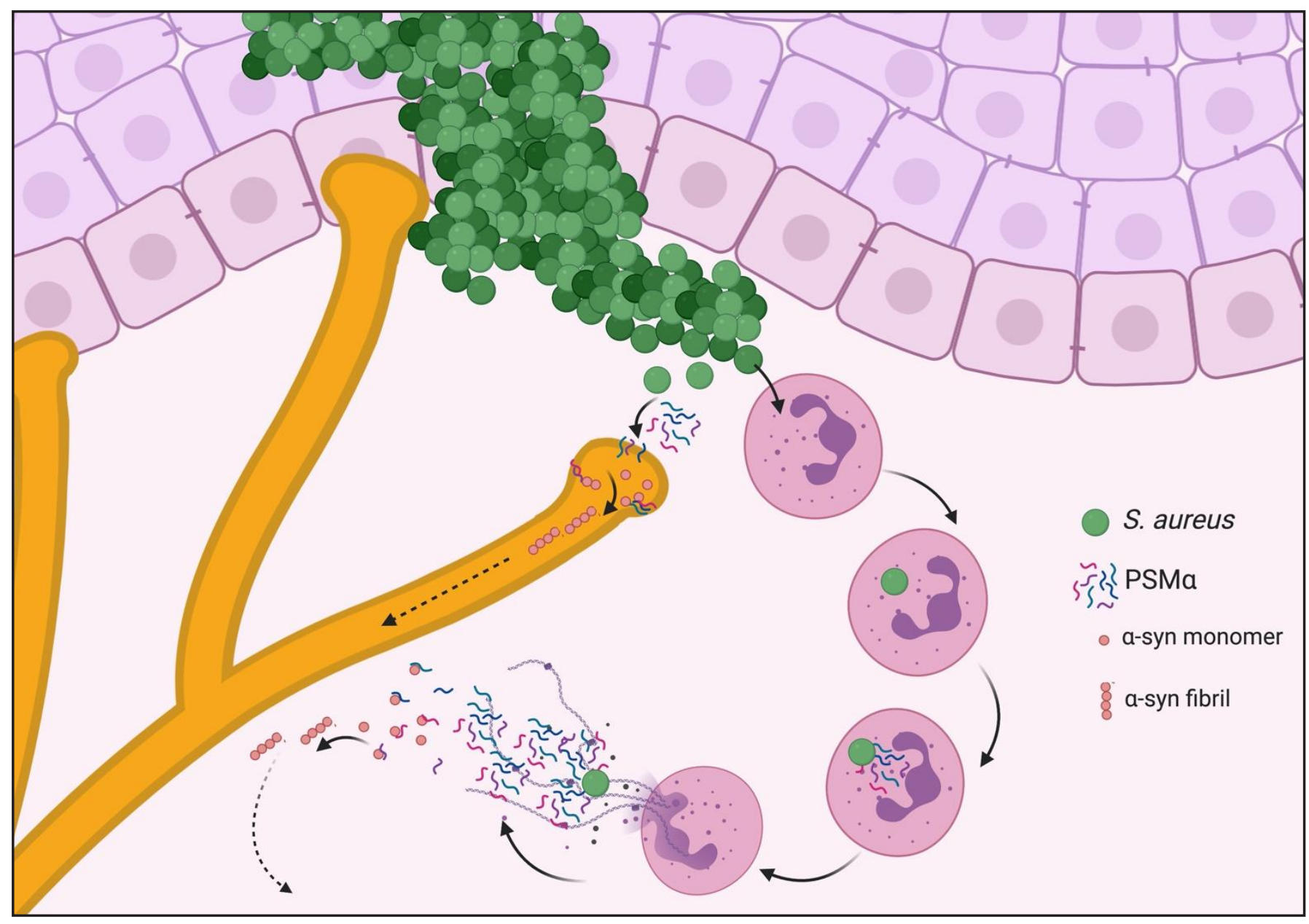

(C)

Figure 4. Schematic illustration of outlining possible modes of PSM $\alpha$-induced $\alpha$-syn aggregation. Cartoon illustrating two of many possible modes of cross-catalysis between PSM $\alpha$ (blue) and $\alpha$-syn (red) involving heterogeneous primary nucleation. The curved arrows indicate the autocatalytic cycles that may result from homogenous secondary nucleation of each peptide on the fibrils of the same peptide. (A) Cross catalysis occurs via heterogeneous primary nucleation in joint oligomers, with no cross-catalysis at fibril level. (B) Separate primary nucleation, significant only for PSM $\alpha$, and heterogeneous primary nucleation of $\alpha$-syn on PSM $\alpha$ fibrils. (C) Cartoon illustrating possible routes by which $S$. aureus and 
PSM $\alpha$ s could lead to $\alpha$-syn pathology. Invading S. aureus produces PSM $\alpha$ peptides that are chemoattracting neutrophils. Neutrophils phagocytose $S$. aureus bacteria, whereby PSM $\alpha$ expression is upregulated leading to phagosome escape and NETosis $(24,25,27)$. At high concentrations, the PSM $\alpha$ peptides may interact with extracellular $\alpha$-syn causing aggregation by enhanced primary nucleation, leading to the formation of fibrils, which can propagate and seed $\alpha$-syn in other cells (this study). PSM $\alpha$ peptides also form pores in sensory neurons $(28,29)$. The PSM $\alpha$ peptides may then enter cells and interact with intracellular $\alpha$-syn.

\section{Materials and Methods}

\section{1. $\alpha$-Syn Production and Purification}

Human wildtype $\alpha$-syn was expressed and purified using heat treatment, ion exchange and gel filtration chromatography, as previously described [51]. $\alpha$-Syn samples were aliquoted and stored at $-20^{\circ} \mathrm{C}$.

\subsection{PSM $\alpha$ Production}

The kinetics experiments were performed by two different labs involved in this manuscript.

The four different PSM $\alpha$ peptides were produced by chemical synthesis and isolated using reversed-phase HPLC to $95 \%$ purity (synthesis and purification by the manufacturer) with the following sequences:

PSM $\alpha 1$ : Formyl-MGIIAGIIKVIKSLIEQFTGK

PSM $\alpha 2$ : Formyl-MGIIAGIIKFIKGLIEKFTGK

PSM $\alpha 3$ : Formyl-MEFVAKLFKFFKDLLGKFLGNN

PSM $\alpha$ : Formyl-MAIVGTIIKIIKAIIDIFAK

For the experiments described in Figures S3 and S7 the peptides were purchased from GenScript Biotech, Netherlands, and for all other experiments, they were purchased from EMC microcollections $\mathrm{GmbH}$ as lyophilized peptides.

The lyophilized peptides were stored at $-80{ }^{\circ} \mathrm{C}$ and used without further purification in all experiments except one. For one experiment, PSM $\alpha 2$ was further purified using size exclusion chromatography. The peptide was dissolved at $1.25 \mathrm{mg} / \mathrm{mL}$ in $6 \mathrm{M} \mathrm{GuHCl}$, $10 \mathrm{mM}$ MES and purified using a Superdex Peptide 10/300 GL column in $10 \mathrm{mM}$ Tris, $50 \mathrm{mM} \mathrm{NaCl}, \mathrm{pH} 7.6$, with absorbance measurements at $214 \mathrm{~nm}$ and $256 \mathrm{~nm}$.

\subsection{Aggregation Kinetics Experiments}

In order to obtain reproducible data, monomeric $\alpha$-syn was isolated immediately prior to each experiment. Purified $\alpha$-syn was lyophilized, dissolved in $6 \mathrm{M} \mathrm{GuHCl,10} \mathrm{mM}$ MES, pH 5.5 and purified using size exclusion chromatography into $10 \mathrm{mM}$ MES, pH 5.5 or $10 \mathrm{mM}$ Tris, $50 \mathrm{mM} \mathrm{NaCl}, \mathrm{pH} 7.6$ at the start of every experiment. Buffer solutions were filtered and degassed prior to each run. The purification was monitored by UV absorbance at $280 \mathrm{~nm}$ and only the central monomer peak collected. The absorbance of the collected $\alpha$-syn fraction was measured at $280 \mathrm{~nm}$ and an extinction coefficient of $5960 \mathrm{M}^{-1} \mathrm{~cm}^{-1}$ was used to calculate the concentration. Purified $\alpha$-syn monomer was kept on ice to prevent aggregation.

The PSM $\alpha$ peptides were dissolved in dimethyl sulfoxide (DMSO) to a concentration of $2 \mathrm{mg} / \mathrm{mL}$ and then diluted in buffer. The final DMSO concentration ranged from 0.1 to $8.9 \% v / v$. Complementary $\alpha$-syn aggregation experiments without PSM $\alpha$ peptides were performed at the same DMSO concentrations.

To follow the aggregation process, samples were aliquoted into 96-well black Corning polystyrene half-area microtiter plates with PEGylated surface (Corning 3881) in the presence of $20 \mu \mathrm{M}$ ThT and $0.01 \% \mathrm{NaN}_{3}$. Replicates without ThT were also prepared for additions to cell cultures. For the first round of experiments, the $\alpha$-syn concentration was kept constant at $25 \mu \mathrm{M}$ and PSM $\alpha$ s added at 5 different final concentrations: 1, 3, 9, 26 and $78 \mu \mathrm{M}$. Plates were incubated under quiescent conditions at $37^{\circ} \mathrm{C}$ and the fluorescence was measured for up to $400 \mathrm{~h}$ (excitation filter $440 \mathrm{~nm}$ and emission filter $480 \mathrm{~nm}$ ). Each 
experiment was repeated 1-3 times. These experiments were performed in $10 \mathrm{mM}$ Tris, $50 \mathrm{mM} \mathrm{NaCl}, 20 \mu \mathrm{M}$ ThT, $0.01 \% \mathrm{NaN}_{3}$, pH 7.6 or in $10 \mathrm{mM}$ MES, $20 \mu \mathrm{M}$ ThT, $0.01 \% \mathrm{NaN}_{3}$, $\mathrm{pH}$ 5.5. Data from one experiment, representative of all, are shown in the results section and supplementary information.

For the second round of experiments, the PSM $\alpha$ concentrations were kept constant at $8.6 \mu \mathrm{M}$ and $\alpha$-syn added at concentrations of $1,3,9,26,78$ and $116 \mu \mathrm{M}$. These experiments were performed in $10 \mathrm{mM}$ Tris, $50 \mathrm{mM} \mathrm{NaCl}, \mathrm{pH} 7.6$ in the presence of $20 \mu \mathrm{M}$ ThT and $0.01 \% \mathrm{NaN}_{3}$.

To verify the findings, kinetic experiments were also performed at different solution and surface conditions. For these experiments, described in Figures S3 and S7, the PSM $\alpha$ peptides were dissolved in DMSO to a final concentration of $10 \mathrm{mg} / \mathrm{mL}$ and then diluted with milliQ water to a concentration of $2 \mathrm{mg} / \mathrm{mL}$. Then, they were further diluted into PBS containing $40 \mu \mathrm{M}$ ThT and $50 \mu \mathrm{M} \alpha$-syn at a final volume of $150 \mu \mathrm{L}$ in a 96 well black polystyrene microtiter plates. The dilutions were supplemented with DMSO to a final concentration of $5 \%(v / v)$. In these plates, the aggregation of $\alpha$-syn was triggered by heterogeneous primary nucleation at the polystyrene surface [46]. The ThT fluorescence was monitored under quiescent conditions at $37^{\circ} \mathrm{C}$ and averages of 2 replicates were plotted.

\subsection{Kinetics Analysis}

The data sets from each experiment were analyzed using Amylofit [52]. The ThT curves were normalized and the half time, defined as the point of time at which the ThT fluorescence has reached half-way in between the starting baseline and ending plateau, was extracted. For $\alpha$-syn incubated on its own or in the presence of DMSO, the ThT curves were normalized to the values of $\alpha$-syn aggregated in the presence of the highest concentrations of PSM $\alpha$ from the same experiment. For PSM $\alpha 2$ and PSM $\alpha 3$ peptides incubated on their own, as the values did not increase, the ThT curves were normalized relative to the values of $\alpha$-syn aggregated in the presence of the highest concentrations of the respective PSM $\alpha$ from the same plate. For the experiment shown in Figure S5, the ThT curves for fraction 1 and fraction 7 as well as $\alpha$-syn only were normalized relative to the values from fraction 4 . The averages and standard deviations of the half-times of 3 or 4 replicates for each condition were plotted against the concentrations of PSM $\alpha$ peptides or $\alpha$-syn. Models of primary nucleation and elongation only or models also accounting for secondary nucleation were fitted to the kinetics data from the aggregation of $\alpha$-syn in the presence of varying concentrations of the different PSM $\alpha$ peptides.

\subsection{Electrophoresis and Mass Spectrometry}

The samples were analyzed by SDS-PAGE using Novex 10-20\% Tricine precast gels and Tris/Tricine SDS Running buffer (100 mM Tris base; $100 \mathrm{mM}$ Tricine; 0.1\% SDS; $\mathrm{pH}=8.3) .20 \mu \mathrm{L}$ of each sample were mixed with $5 \mu \mathrm{L}$ of gel loading buffer (1.66 M Tris; 44.4\% glycerol; 9.3\% SDS; 9.3\% ß-mercaptoethanol; 0.093\% Coomassie Blue). $10 \mu \mathrm{L}$ of each mixture were loaded, and the gel was run at $70 \mathrm{~V}$ for $15 \mathrm{~min}$, followed by $120 \mathrm{~V}$ for $1 \mathrm{~h}$. The gel was stained with InstantBlue ${ }^{\mathrm{TM}}$ overnight for optimal band detection. Gel bands of interest were excised and subjected to in-gel digestion. Gel pieces $\left(1 \times 1 \mathrm{~mm}^{2}\right)$ were washed twice in $50 \mathrm{mM}$ ammonium bicarbonate $\left(\mathrm{NH}_{4} \mathrm{HCO}_{3}\right) / 50 \%$ acetonitrile $(\mathrm{ACN})$, followed by dehydrated in $100 \%$ ACN. Digestion was performed by adding $50 \mathrm{mM} \mathrm{NH}_{4} \mathrm{HCO}_{3}$ with $12 \mathrm{ng} / \mu \mathrm{L}$ sequencing-grade modified trypsin (Promega, Madison, WI, USA), incubation on ice for $4 \mathrm{~h}$ before overnight incubation at $37^{\circ} \mathrm{C}$. The next day trifluoroacetic acid (TFA) was added to a final concentration of $0.5 \%$ and the peptide containing solution above the gel pieces was withdrawn and used for further analysis. Mass spectrometry analysis was performed in reflector positive mode on an Autoflex Speed MALDI TOF/TOF mass spectrometer (Bruker Daltonics, Bremen, Germany). All peptide mass spectra were externally calibrated using Bruker Peptide Calibration Standard II. 


\subsection{Peptide Array}

To probe interactions between $\alpha$-syn and the PSM $\alpha$ s, 48 different 10-residue peptides corresponding to different parts of the PSM sequences were immobilized on a microarray chip and incubated with Alexa-fluor488-labelled $\alpha$-syn. In this array, each new peptide constituted a 10-residue window of a given PSM sequence shifted forward by 1 residue compared to the preceding peptide, giving a 9-residue overlap.

As part of this procedure, the microarray was first blocked in a solution containing $3 \%$ $(w / v)$ skim milk in PBS with $0.1 \%$ Tween-20 incubated overnight at $4{ }^{\circ} \mathrm{C}$ and washed three times with $25 \mathrm{mM}$ TBS with $0.1 \%$ Tween-20 (TSB-T). Subsequently it was incubated with Alexa-fluor 488 -labelled $\alpha$-syn (diluted to $0.5 \mathrm{mg} / \mathrm{mL}$ in PBS) for $4 \mathrm{~h}$ at room temperature. The microarray was washed 3 times with TSB-T, air-dried in the dark and scanned using a Typhoon Trio scanner (GE Life Sciences, Pittsburgh, PA, USA). Dot intensities in the scanned image were quantified using ImageJ.

\subsection{Electron Microscopy}

Samples were diluted 1:500 in sterile phosphate buffered saline (HyClone, 10126473, Utah, UT, USA) and $5 \mu \mathrm{L}$ diluted sample added onto carbon-coated grids (made in-house). After washing in distilled $\mathrm{H}_{2} \mathrm{O}$, the surface was blocked with bovine serum albumin (Sigma, A2153, Missouri, MO, USA) to prevent nonspecific binding and the specimens then incubated with 1:200 syn211 (sc-12767) for $1 \mathrm{~h}$. Samples were again washed in distilled $\mathrm{H}_{2} \mathrm{O}$, incubated with 1:20 10 nm gold-anti-mouse antibody (Ted Pella, 15751, California, CA, USA), washed, fixed first with glutaraldehyde (Ted Pella 18427) and then uranyl acetate (Agar Scientific R1260A, Essex, UK). The samples then were examined under a transmission electron microscope (TEM) (FEI Tecnai Biotwin 120 kV, Minnesota, MN, USA).

\subsection{HEK 293T Culture}

HEK 293T cells were stably transduced with the A53T mutant of $\alpha$-syn fused to GFP and were maintained in DMEM GlutaMAX (Gibco 10569010, Texas, TX, USA) supplemented with $10 \%$ fetal bovine serum (Gibco 10270-106) and 1\% penicillin-streptomycin (Gibco 15140-122) and split every three days.

For live-imaging experiments, cells were split 1:20,000 into collagen G-coated (Biochrom GmbH L7213, Berlin, Germany) black, clear bottom 96-well plates. Samples of $\alpha$-syn and $\mathrm{PSM} \alpha$ incubated separately or together were sonicated at $100 \%$ amplitude for $3 \mathrm{~min}$ at $50 \%$ duty cycle ( $1 \mathrm{~s}$ on, $1 \mathrm{~s}$ off). $10 \mu \mathrm{L}$ of each sample was added in 4 or 3 replicates into $100 \mu \mathrm{L}$ medium. The plates were imaged for $48 \mathrm{~h}$ with $1 \mathrm{~h}$ intervals using a Nikon Ti-E microscope with $95 \%$ humidity $5 \% \mathrm{CO}_{2}$.

\subsection{Phospho- $\alpha$-Syn Staining of HEK 293T Cells}

After $48 \mathrm{~h}$, the cells were fixed with phosphate-buffered paraformaldehyde $\mathrm{pH} 7.4$ by slow addition into the cell medium to a final concentration of $2 \%$ for $20 \mathrm{~min}$. The cells were then washed and kept at $4{ }^{\circ} \mathrm{C}$. Cells were then permeabilized and blocked with $5 \%$ normal donkey serum (NDS) $0.25 \%$ Tween 20 in PBS. Primary antibody pS129 $\alpha$-syn (Abcam 51253, Cambridge, UK) was added at 1:1000 overnight and the plates kept at $4{ }^{\circ} \mathrm{C}$. The cells were washed and incubated with 1:600 Cy3 conjugated anti-rabbit antibody (Jackson Immunolabs 711-165-152), washed and then imaged again. For each well, 25 $(5 \times 5$ square $)$ images were acquired with a $20 \times$ objective.

\subsection{Quantification of Aggregates}

Quantification of the number of GFP-aggregates and pS129 $\alpha$-syn inclusions was performed using Cell Profiler. In brief, cell nuclei were identified as primary objects by segmentation by diameter sizes and counted in the GFP channel with a global thresholding strategy. In the GFP channel and the Cy-3 channel, aggregates and phosphorylated aggregates, respectively, were identified as secondary objects by segmentation by diameter size and counted using an Otsu adaptive thresholding strategy, which separates foreground 
from background, optimally used when percentage of the image covered by foreground varies substantially from image to image. The number of aggregates and cells were quantified per well. The number of aggregates and phosphorylated aggregates per 100 cells were determined per well and averages from 4 replicates were plotted for each condition.

Supplementary Materials: The following are available online at https:/ / www.mdpi.com/article/10 $.3390 /$ ijms222111594/s1.

Author Contributions: Conceptualization, C.H., J.-Y.L. and S.L.; methodology, C.H., L.O.-P., Z.N., K.B. and A.S.; software, C.H. and K.B.; validation, C.H., L.O.-P. and Z.N.; formal analysis, C.H., S.L. and J.-Y.L.; investigation, C.H., L.O.-P., Z.N., K.B. and A.S.; resources, D.E.O., S.L. and J.-Y.L.; data curation, C.H., S.L. and J.-Y.L.; writing-original draft preparation, C.H.; writing-review and editing, L.O.-P., Z.N., K.B., A.S., D.E.O., S.L., J.-Y.L.; visualization, C.H., L.O.-P., K.B., Z.N., S.L., J.-Y.L.; supervision, S.L. and J.-Y.L.; project administration, C.H., S.L. and J.-Y.L.; funding acquisition, D.E.O., S.L. and J.-Y.L. All authors have read and agreed to the published version of the manuscript.

Funding: We acknowledge financial supports by The Swedish Research Council (K2015-61X-2229703-4; 2019-01551; 2015-00143), EU-JPND research (aSynProtec and REfrAME) and EU-Horizon2020 (MSCA-ITN-2016, SynDeGen), ParkinsonFonden, the Strategic Research Area Multipark (Multidisciplinary research in Parkinson's disease at Lund University) and the National Natural Science Foundation of China (81430025, 31800898, and U1801681) and the Key Field Research Development Program of Guangdong Province (2018B030337001). D. E. O. is supported by the Innovation Foundation Denmark (Grant 5188-00003B) through the Joint Programme on Neurodegenerative Diseases (aSynProtec) and the Independent Research Foundation Denmark I Technical Sciences (grant no. 6111-00241B).

Institutional Review Board Statement: Not applicable.

Informed Consent Statement: Not applicable.

Data Availability Statement: All raw data is available upon reasonable request.

Acknowledgments: The authors would like to thank Johan Bylund for his generous contribution of an aliquot each of PSM $\alpha 2$ and PSM $\alpha 3$ for the pilot experiments. The authors would also like to thank LBIC and Lina Gefors for guidance with the Transmission Electron Microscopy, Birgitta Frohm for guidance with the Size Exclusion Chromatography and EMC microcollections for production of the $\mathrm{PSM} \alpha$ peptides. BioRender was used for the illustration in Figure 4.

Conflicts of Interest: The authors declare no conflict of interest.

\section{References}

1. Braak, H.; Rub, U.; Gai, W.P.; Del Tredici, K. Idiopathic Parkinson's disease: Possible routes by which vulnerable neuronal types may be subject to neuroinvasion by an unknown pathogen. J. Neural Transm. 2003, 110, 517-536. [CrossRef] [PubMed]

2. Hawkes, C.H.; Del Tredici, K.; Braak, H. Parkinson's disease: A dual-hit hypothesis. Neuropathol. Appl. Neurobiol. 2007, 33, 599-614. [CrossRef]

3. Holmqvist, S.; Chutna, O.; Bousset, L.; Aldrin-Kirk, P.; Li, W.; Bjorklund, T.; Wang, Z.Y.; Roybon, L.; Melki, R.; Li, J.Y. Direct evidence of Parkinson pathology spread from the gastrointestinal tract to the brain in rats. Acta Neuropathol. 2014, 128, 805-820. [CrossRef] [PubMed]

4. Kim, S.; Kwon, S.H.; Kam, T.I.; Panicker, N.; Karuppagounder, S.S.; Lee, S.; Lee, J.H.; Kim, W.R.; Kook, M.; Foss, C.A.; et al. Transneuronal Propagation of Pathologic alpha-Synuclein from the Gut to the Brain Models Parkinson's Disease. Neuron 2019, 103, 627-641. [CrossRef]

5. Wang, X.J.; Ma, M.M.; Zhou, L.B.; Jiang, X.Y.; Hao, M.M.; Teng, R.K.F.; Wu, E.; Tang, B.S.; Li, J.Y.; Teng, J.F.; et al. Autonomic ganglionic injection of alpha-synuclein fibrils as a model of pure autonomic failure alpha-synucleinopathy. Nat. Commun. 2020, 11, 934. [CrossRef] [PubMed]

6. Lohmann, S.; Bernis, M.E.; Tachu, B.J.; Ziemski, A.; Grigoletto, J.; Tamguney, G. Oral and intravenous transmission of alphasynuclein fibrils to mice. Acta Neuropathol. 2019, 138, 515-533. [CrossRef] [PubMed]

7. Rey, N.L.; George, S.; Steiner, J.A.; Madaj, Z.; Luk, K.C.; Trojanowski, J.Q.; Lee, V.M.; Brundin, P. Spread of aggregates after olfactory bulb injection of alpha-synuclein fibrils is associated with early neuronal loss and is reduced long term. Acta Neuropathol. 2018, 135, 65-83. [CrossRef]

8. Rey, N.L.; Petit, G.H.; Bousset, L.; Melki, R.; Brundin, P. Transfer of human alpha-synuclein from the olfactory bulb to interconnected brain regions in mice. Acta Neuropathol. 2013, 126, 555-573. [CrossRef] [PubMed] 
9. Rey, N.L.; Steiner, J.A.; Maroof, N.; Luk, K.C.; Madaj, Z.; Trojanowski, J.Q.; Lee, V.M.; Brundin, P. Widespread transneuronal propagation of alpha-synucleinopathy triggered in olfactory bulb mimics prodromal Parkinson's disease. J. Exp. Med. 2016, 213, 1759-1778. [CrossRef]

10. Bhattacharyya, D.; Mohite, G.M.; Krishnamoorthy, J.; Gayen, N.; Mehra, S.; Navalkar, A.; Kotler, S.A.; Ratha, B.N.; Ghosh, A.; Kumar, R.; et al. Lipopolysaccharide from Gut Microbiota Modulates alpha-Synuclein Aggregation and Alters Its Biological Function. ACS Chem. Neurosci. 2019, 10, 2229-2236. [CrossRef]

11. Chorell, E.; Andersson, E.; Evans, M.L.; Jain, N.; Gotheson, A.; Aden, J.; Chapman, M.R.; Almqvist, F.; Wittung-Stafshede, P. Bacterial Chaperones CsgE and CsgC Differentially Modulate Human alpha-Synuclein Amyloid Formation via Transient Contacts. PLoS ONE 2015, 10, e0140194. [CrossRef] [PubMed]

12. Kim, C.; Lv, G.; Lee, J.S.; Jung, B.C.; Masuda-Suzukake, M.; Hong, C.S.; Valera, E.; Lee, H.J.; Paik, S.R.; Hasegawa, M.; et al. Exposure to bacterial endotoxin generates a distinct strain of alpha-synuclein fibril. Sci. Rep. 2016, 6, 30891. [CrossRef] [PubMed]

13. Guo, J.L.; Covell, D.J.; Daniels, J.P.; Iba, M.; Stieber, A.; Zhang, B.; Riddle, D.M.; Kwong, L.K.; Xu, Y.; Trojanowski, J.Q.; et al. Distinct alpha-synuclein strains differentially promote tau inclusions in neurons. Cell 2013, 154, 103-117. [CrossRef]

14. Chia, S.; Flagmeier, P.; Habchi, J.; Lattanzi, V.; Linse, S.; Dobson, C.M.; Knowles, T.P.J.; Vendruscolo, M. Monomeric and fibrillar alpha-synuclein exert opposite effects on the catalytic cycle that promotes the proliferation of Abeta42 aggregates. Proc. Natl. Acad. Sci. USA 2017, 114, 8005-8010. [CrossRef] [PubMed]

15. Chen, S.G.; Stribinskis, V.; Rane, M.J.; Demuth, D.R.; Gozal, E.; Roberts, A.M.; Jagadapillai, R.; Liu, R.; Choe, K.; Shivakumar, B.; et al. Exposure to the Functional Bacterial Amyloid Protein Curli Enhances Alpha-Synuclein Aggregation in Aged Fischer 344 Rats and Caenorhabditis elegans. Sci. Rep. 2016, 6, 34477. [CrossRef]

16. Romero, D.; Kolter, R. Functional amyloids in bacteria. Int. Microbiol. 2014, 17, 65-73. [CrossRef] [PubMed]

17. Benfield, T.; Espersen, F.; Frimodt-Moller, N.; Jensen, A.G.; Larsen, A.R.; Pallesen, L.V.; Skov, R.; Westh, H.; Skinhoj, P. Increasing incidence but decreasing in-hospital mortality of adult Staphylococcus aureus bacteraemia between 1981 and 2000. Clin. Microbiol. Infect. 2007, 13, 257-263. [CrossRef]

18. Acton, D.S.; Plat-Sinnige, M.J.; van Wamel, W.; de Groot, N.; van Belkum, A. Intestinal carriage of Staphylococcus aureus: How does its frequency compare with that of nasal carriage and what is its clinical impact? Eur. J. Clin. Microbiol. Infect. Dis. 2009, 28, 115-127. [CrossRef]

19. Dong, D.; Ni, Q.; Wang, C.; Zhang, L.; Li, Z.; Jiang, C.; Peng, Y. Effects of intestinal colonization by Clostridium difficile and Staphylococcus aureus on microbiota diversity in healthy individuals in China. BMC Infect. Dis. 2018, 18, 207. [CrossRef] [PubMed]

20. Kates, A.E.; Thapaliya, D.; Smith, T.C.; Chorazy, M.L. Prevalence and molecular characterization of Staphylococcus aureus from human stool samples. Antimicrob. Resist. Infect. Control 2018, 7, 42. [CrossRef]

21. Kluytmans, J.; van Belkum, A.; Verbrugh, H. Nasal carriage of Staphylococcus aureus: Epidemiology, underlying mechanisms, and associated risks. Clin. Microbiol. Rev. 1997, 10, 505-520. [CrossRef] [PubMed]

22. Najarzadeh, Z.; Zaman, M.; Sereikaite, V.; Stromgaard, K.; Andreasen, M.; Otzen, D.E. Heparin promotes fibrillation of most phenol soluble modulin virulence peptides from S. aureus. J. Biol. Chem. 2021, 100953. [CrossRef] [PubMed]

23. Wang, R.; Braughton, K.R.; Kretschmer, D.; Bach, T.H.; Queck, S.Y.; Li, M.; Kennedy, A.D.; Dorward, D.W.; Klebanoff, S.J.; Peschel, A.; et al. Identification of novel cytolytic peptides as key virulence determinants for community-associated MRSA. Nat. Med. 2007, 13, 1510-1514. [CrossRef] [PubMed]

24. Bjornsdottir, H.; Dahlstrand Rudin, A.; Klose, F.P.; Elmwall, J.; Welin, A.; Stylianou, M.; Christenson, K.; Urban, C.F.; Forsman, H.; Dahlgren, C.; et al. Phenol-Soluble Modulin alpha Peptide Toxins from Aggressive Staphylococcus aureus Induce Rapid Formation of Neutrophil Extracellular Traps through a Reactive Oxygen Species-Independent Pathway. Front. Immunol. 2017, 8, 257. [CrossRef]

25. Greenlee-Wacker, M.; DeLeo, F.R.; Nauseef, W.M. How methicillin-resistant Staphylococcus aureus evade neutrophil killing. Curr. Opin. Hematol. 2015, 22, 30-35. [CrossRef] [PubMed]

26. McGuinness, W.A.; Kobayashi, S.D.; DeLeo, F.R. Evasion of Neutrophil Killing by Staphylococcus aureus. Pathogens 2016, 5, 32. [CrossRef] [PubMed]

27. Azevedo, E.P.; Guimaraes-Costa, A.B.; Torezani, G.S.; Braga, C.A.; Palhano, F.L.; Kelly, J.W.; Saraiva, E.M.; Foguel, D. Amyloid fibrils trigger the release of neutrophil extracellular traps (NETs), causing fibril fragmentation by NET-associated elastase. J. Biol. Chem. 2012, 287, 37206-37218. [CrossRef] [PubMed]

28. Chiu, I.M.; Heesters, B.A.; Ghasemlou, N.; Von Hehn, C.A.; Zhao, F.; Tran, J.; Wainger, B.; Strominger, A.; Muralidharan, S.; Horswill, A.R.; et al. Bacteria activate sensory neurons that modulate pain and inflammation. Nature 2013, 501, 52-57. [CrossRef]

29. Blake, K.J.; Baral, P.; Voisin, T.; Lubkin, A.; Pinho-Ribeiro, F.A.; Adams, K.L.; Roberson, D.P.; Ma, Y.C.; Otto, M.; Woolf, C.J.; et al. Staphylococcus aureus produces pain through pore-forming toxins and neuronal TRPV1 that is silenced by QX-314. Nat. Commun. 2018, 9, 37. [CrossRef] [PubMed]

30. Uhlig, F.; Grundy, L.; Garcia-Caraballo, S.; Brierley, S.M.; Foster, S.J.; Grundy, D. Identification of a Quorum Sensing-Dependent Communication Pathway Mediating Bacteria-Gut-Brain Cross Talk. iScience 2020, 23, 101695. [CrossRef]

31. Valek, L.; Auburger, G.; Tegeder, I. Sensory neuropathy and nociception in rodent models of Parkinson's disease. Dis. Model. Mech. 2019, 12. [CrossRef] [PubMed] 
32. Braak, H.; Sastre, M.; Bohl, J.R.; de Vos, R.A.; Del Tredici, K. Parkinson's disease: Lesions in dorsal horn layer I, involvement of parasympathetic and sympathetic pre- and postganglionic neurons. Acta Neuropathol. 2007, 113, 421-429. [CrossRef] [PubMed]

33. Beach, T.G.; Adler, C.H.; Sue, L.I.; Vedders, L.; Lue, L.; White Iii, C.L.; Akiyama, H.; Caviness, J.N.; Shill, H.A.; Sabbagh, M.N.; et al. Multi-organ distribution of phosphorylated alpha-synuclein histopathology in subjects with Lewy body disorders. Acta Neuropathol. 2010, 119, 689-702. [CrossRef]

34. Sumikura, H.; Takao, M.; Hatsuta, H.; Ito, S.; Nakano, Y.; Uchino, A.; Nogami, A.; Saito, Y.; Mochizuki, H.; Murayama, S. Distribution of alpha-synuclein in the spinal cord and dorsal root ganglia in an autopsy cohort of elderly persons. Acta Neuropathol. Commun. 2015, 3, 57. [CrossRef] [PubMed]

35. Marinelli, P.; Pallares, I.; Navarro, S.; Ventura, S. Dissecting the contribution of Staphylococcus aureus alpha-phenol-soluble modulins to biofilm amyloid structure. Sci. Rep. 2016, 6, 34552. [CrossRef]

36. Tayeb-Fligelman, E.; Tabachnikov, O.; Moshe, A.; Goldshmidt-Tran, O.; Sawaya, M.R.; Coquelle, N.; Colletier, J.P.; Landau, M. The cytotoxic Staphylococcus aureus PSMalpha3 reveals a cross-alpha amyloid-like fibril. Science 2017, 355, 831-833. [CrossRef]

37. Galvagnion, C.; Buell, A.K.; Meisl, G.; Michaels, T.C.; Vendruscolo, M.; Knowles, T.P.; Dobson, C.M. Lipid vesicles trigger alpha-synuclein aggregation by stimulating primary nucleation. Nat. Chem. Biol. 2015, 11, 229-234. [CrossRef]

38. Habchi, J.; Chia, S.; Galvagnion, C.; Michaels, T.C.T.; Bellaiche, M.M.J.; Ruggeri, F.S.; Sanguanini, M.; Idini, I.; Kumita, J.R.; Sparr, E.; et al. Cholesterol catalyses Abeta42 aggregation through a heterogeneous nucleation pathway in the presence of lipid membranes. Nat. Chem. 2018, 10, 673-683. [CrossRef]

39. Cukalevski, R.; Yang, X.; Meisl, G.; Weininger, U.; Bernfur, K.; Frohm, B.; Knowles, T.P.J.; Linse, S. The Abeta40 and Abeta42 peptides self-assemble into separate homomolecular fibrils in binary mixtures but cross-react during primary nucleation. Chem. Sci. 2015, 6, 4215-4233. [CrossRef] [PubMed]

40. de Oliveira, G.A.P.; Silva, J.L. Alpha-synuclein stepwise aggregation reveals features of an early onset mutation in Parkinson's disease. Commun. Biol. 2019, 2, 374. [CrossRef]

41. Arosio, P.; Cukalevski, R.; Frohm, B.; Knowles, T.P.; Linse, S. Quantification of the concentration of Abeta42 propagons during the lag phase by an amyloid chain reaction assay. J. Am. Chem. Soc. 2014, 136, 219-225. [CrossRef] [PubMed]

42. Arosio, P.; Knowles, T.P.; Linse, S. On the lag phase in amyloid fibril formation. Phys. Chem. Chem. Phys. 2015, 17, 7606-7618. [CrossRef]

43. Svanbergsson, A.; Ek, F.; Martinsson, I.; Rodo, J.; Liu, D.; Brandi, E.; Haikal, C.; Torres-Garcia, L.; Li, W.; Gouras, G.; et al. FRET-Based Screening Identifies p38 MAPK and PKC Inhibition as Targets for Prevention of Seeded alpha-Synuclein Aggregation. Neurotherapeutics 2021. [CrossRef]

44. Linse, S. Monomer-dependent secondary nucleation in amyloid formation. Biophys. Rev. 2017, 9, 329-338. [CrossRef]

45. Buell, A.K.; Galvagnion, C.; Gaspar, R.; Sparr, E.; Vendruscolo, M.; Knowles, T.P.; Linse, S.; Dobson, C.M. Solution conditions determine the relative importance of nucleation and growth processes in alpha-synuclein aggregation. Proc. Natl. Acad. Sci. USA 2014, 111, 7671-7676. [CrossRef]

46. Vacha, R.; Linse, S.; Lund, M. Surface effects on aggregation kinetics of amyloidogenic peptides. J. Am. Chem. Soc. 2014, 136, 11776-11782. [CrossRef] [PubMed]

47. Campioni, S.; Carret, G.; Jordens, S.; Nicoud, L.; Mezzenga, R.; Riek, R. The presence of an air-water interface affects formation and elongation of alpha-Synuclein fibrils. J. Am. Chem. Soc. 2014, 136, 2866-2875. [CrossRef]

48. Gaspar, R.; Lund, M.; Sparr, E.; Linse, S. Anomalous Salt Dependence Reveals an Interplay of Attractive and Repulsive Electrostatic Interactions in $\alpha$-synuclein Fibril Formation. QRB Discov. 2020, 1, e2. [CrossRef]

49. Zaman, M.; Andreasen, M. Modulating Kinetics of the Amyloid-Like Aggregation of S. aureus Phenol-Soluble Modulins by Changes in $\mathrm{pH}$. Microorganisms 2021, 9, 117. [CrossRef]

50. Krismer, B.; Peschel, A. Does Staphylococcus aureus nasal colonization involve biofilm formation? Future Microbiol. 2011, 6, 489-493. [CrossRef] [PubMed]

51. Grey, M.; Linse, S.; Nilsson, H.; Brundin, P.; Sparr, E. Membrane interaction of alpha-synuclein in different aggregation states. J. Parkinson's Dis. 2011, 1, 359-371. [CrossRef] [PubMed]

52. Meisl, G.; Kirkegaard, J.B.; Arosio, P.; Michaels, T.C.; Vendruscolo, M.; Dobson, C.M.; Linse, S.; Knowles, T.P. Molecular mechanisms of protein aggregation from global fitting of kinetic models. Nat. Protoc. 2016, 11, 252-272. [CrossRef] [PubMed] 